\title{
Effect of Foreign Portfolio Investment in Bond Stocks on the Performance of the Nigerian Stock Market
}

\author{
Grace 0. Iriobe \\ Lecturer, Department of Financial Studies, \\ College of Management and Social sciences, \\ Redeemer's University, Ede, Nigeria. \\ Tomola M. Obamuyi (PhD) \\ Professor, Department of Economics, \\ School of Management Technology, \\ Federal University of Technology, Akure, Nigeria. \\ Muftau A. Abayomi (PhD) \\ Lecturer, Department of Economics, \\ School of Management Technology, \\ Federal University of Technology, Akure, Nigeria.
}

\begin{abstract}
Emerging markets like Nigeria have consistently utilized foreign portfolio investments inflows to boost the economy. While economies consistently harness Foreign Portfolio Investment (FPI) in equity stocks to grow the economy, the report on foreign portfolio investments in bond stocks is too low to bridge the savings-investment gap in the economy. Therefore, this study examines the effect of foreign portfolio investment in bond stocks on the performance of the Nigerian stock market. The study employed expost facto research method using monthly time series data from 2007 to 2017. Using the Auto-Regressive Distributed Lag (ARDL) model, the study found that foreign portfolio investment in bond stocks have a positive and significant influence on the Nigerian stock market performance at $5 \%$ level $\left(t-s t a t=2.91380, P=0.0038<0.05 ; R^{2}=\right.$ 0.73). The study concludes that foreign portfolio investment in bond stocks significantly predict stock market performance in Nigeria, and therefore recommends that the market regulators need to further encourage foreign investments in bond stocks as this financial instruments do not attract much investment as equity stocks. Also, there is need for sound corporate governance and transparency as well as full disclosure of financial information by listed firms in order to increase the attraction of foreign portfolio investment in debt stocks to Nigeria.
\end{abstract}

Keywords: Foreign portfolio investments, Bond Stocks, Stock market performance Word Count: 207

\section{INTRODUCTION}

FPI include several instruments that are traded in any organized and other financial markets. These instruments are bonds, equity, and money market instruments. Historically, FPI is seen as a source of foreign private capital to every economy. Its role in positioning a country for socioeconomic development cannot be overemphasized (Charles, Takaaki \& Akiko, 2014). Since no country is an island on its own, in terms of resources needed to stimulate investment, generate employment and foster economic growth, recourse must be made from time to time to encourage foreign investment to bridge the financial gaps between revenue and planned expenditure, balance of payment differences, terms of trade, and so on (Idowu \& Babatunde, 2012). 
According to Ekeocha (2008), FPI occurs when investors purchase non-controlling interests in foreign companies or buy foreign corporate or government bonds, short-term securities, or notes. This is to say that just as trade flows result from individuals and countries seeking to maximize their well-being by exploiting their own comparative advantage, so is capital flows the result of individuals and countries seeking to make themselves better off, moving accumulated assets to wherever they are likely to be most productive. This type of investment has become a very significant part of the world economy over some decades now, and it serves as an important source of fund to support investment not only in developed world but developing countries as well (Elekwa, Aniebo \& Ogu, 2016). The importance of foreign portfolio investment to foreign investors is that the investors can demand better rules and regulations from the local markets. These rules primarily concern the information quality and quantity while better disclosure and higher accounting standard are part of regulations (Elekwa et al, 2016). Hence, financial markets become more transparent with the participation of foreigners, leading to better allocation of resources and healthier financial markets. In the opinion of Ghose (2004), FPI contributes to economic growth in developing countries through two channels; one of which is externalities in the form of positive productivity spill-over to domestic enterprises. Hence, Dauda (2007) opine that foreign capital investment increases the gross domestic product and generates a stream of real incomes in the host country, which consequently expands employment, raises wages and salaries, lower commodity prices, increase tax revenue accruable to the government. Also, UNCTAD (2005) observed that foreign investment in Africa has advanced much further and faster than internal integration, especially in structural, institutional and policy trends. However, literatures have focused only on the equity participation of portfolio investments while ignoring investment in debt stocks (Roberto \& Paul, 2007; Egly, Johnk \& Liston, 2010; Osinubi \& Amaghionyeodiwe, 2010; Lahiri, 2012; Okpoto, 2015; Gerlach \& Yook, 2016).

In this light, the objective of the study was to examine the influence of FPI in debt stocks and its influence on the Performance of the Nigerian Stock Market.

Ho1: Foreign Portfolio Investment in Bond stocks does not have significant influence on the Volume of Transaction in the Nigerian stock Market.

\section{LITERATURE REVIEW}

Horioka, Nomoto and Terada-Hagiwara (2014) argued that foreign portfolio investment in bond stocks are mere investment in debt instruments. However, Egly, Johnk and Liston (2010) opine that foreign portfolio investment in bond stocks basically involves investment in debt instruments such as treasury bills. Also, Mishra et al, (2014) noted that literature have focused on equities with little analysis of bonds because of the scarce bond market data. This is to say that information on bonds is not readily available across economies of the world. Hence, Portes and Rey (2005) posited that in studying the geography of bond flows between foreign economies, trading in corporate bonds require a deeper knowledge of the host countries' accounting practices, corporate culture, political events, and their current business conditions.

Burger and Warnock (2003) found that US investors prefer to make foreign portfolio investments in bond stocks with countries who have more open capital accounts and whose bond returns are less correlated with their own portfolio returns, while Lane (2006) investigated the bilateral composition of investments in foreign bond portfolios for the euro area and found a positive connection between trade linkages, financial linkages, and financial regionalization as a leading determinant of financial globalization. Also, Fang, Lu, Yau and Lee (2013) found that domestic investors benefit from foreign investments in bonds using a 
weekly industry-level data to analyse the diversification strategies in foreign portfolio investments.

This study adds that foreign portfolio investment also includes the purchase of bond stocks/instruments issued by a foreign government. Hence, the investigation into the influence of foreign portfolio investment in bond stocks on the performance of the Nigerian Stock Market.

\section{METHODOLOGY}

This paper employed time series quarterly data covering 11 years (2007-2017) to estimate the long-run and causal relationships between foreign portfolio investments in bond stocks and stock market performance in Nigeria. The data was sourced from the Nigerian Stock Exchange reports, Central Bank of Nigeria (CBN) statistical Bulletins, World Development Indicators (WDI), National Bureau of statistics, IMF World Economic Outlook, World Investment Report by United Nations Conference on Trade and Development (UNCTAD), and the CBN Journal of Applied Statistics.

The study employed an empirical analysis with Autoregressive Distributed Lag Model (ARDL) to evaluate the hypotheses with the help of the Econometric View (E-view) Version 8 econometrics package.

\section{Model specification}

The expression that foreign portfolio investment in bond stocks has a relationship with volume of transactions in the Nigerian stock market can be explained by the equation below:

$$
\text { VOT= } \mathrm{f}(\mathrm{PBS}, \text { FID, EXR, IFR, ITR). }
$$

Where,

PBS= Monthly Foreign Portfolio Investments in Bond Stocks Nigeria

FID = Monthly Financial Development Measured by the $\mathrm{M}_{2} / \mathrm{GDP}$

EXR= Monthly Exchange Rate of the Naira/Dollar

IFR= Monthly Inflation Rate measured by a change in Consumer Price Index (CPI)

ITR= Monthly Prime Lending Rate in Nigeria

The model in its stochastic form:

$$
\operatorname{VOT}_{\mathrm{t}}=\beta_{0}+\beta_{1} \mathrm{PBS}_{\mathrm{t}}+\beta_{2} \mathrm{FID}_{\mathrm{t}}+\beta_{3} \mathrm{EXR}_{\mathrm{t}}+\beta_{4} \mathrm{IFR}_{\mathrm{t}}+\beta_{5} \mathrm{ITR}_{\mathrm{t}}+\mu
$$

Introducing lag operator and Error Correction Model, the parsimonious ECM for foreign portfolio investment in bond stocks is:

VOT $_{t}=\beta_{0}+\beta_{1}$ PBS $_{t}+\beta_{2}$ PBS $_{t-1}+\beta_{3}$ FID $_{t}+\beta_{4} \mathrm{FID}_{\mathrm{t}-1}+\beta_{5} \mathrm{EXR}_{\mathrm{t}}+\beta_{6} \mathrm{EXR}_{\mathrm{t}-1}+\beta_{7} \mathrm{IFR}_{\mathrm{t}}+\beta_{8} \mathrm{IFR}_{\mathrm{t}-1}+\beta_{9} \mathrm{ITR}_{\mathrm{t}}+$ $\beta_{10} \mathrm{ITR}_{\mathrm{t}-1}+\beta_{11} \mathrm{ECM}_{\mathrm{t}}-1+\mu_{\mathrm{t}}$

The equations above are the error correction model with six (6) contemporaneous values (i.e. $\left.\beta_{2}, \beta_{4}, \beta_{6}, \beta_{8}, \beta_{10}\right)$. 


\section{Unit Root Test}

\section{EMPIRICAL RESULTS}

The Augmented Dickey-Fuller (ADF) statistics was used to test for unit root on the study variables. The result shows that the Volume of Transactions in the Nigerian Stock Market (VOT), Foreign Portfolio Investments in Bond Stocks (PBS) were stationary at levels as their ADF statistics were significant at $5 \%$ while it was tested at level. The test also indicated that Financial Development Measure (FID), Exchange Rate (EXR), Inflation Rate (IFR) and Interest Rate (ITR) were stationary at first difference. As a result, the Auto-Regressive Distributed Lag (ARDL) model was employed.

Table 1: Augmented Dickey-Fuller (ADF) Unit Root Test Result

\begin{tabular}{|c|c|c|c|c|c|c|c|c|}
\hline \multirow[b]{2}{*}{ Variable } & \multirow[b]{2}{*}{ Method } & \multicolumn{3}{|l|}{ At Level } & \multicolumn{3}{|c|}{ At First Difference } & \multirow[b]{2}{*}{ Order } \\
\hline & & $\begin{array}{l}\text { ADF } \\
\text { statistics }\end{array}$ & $\begin{array}{l}5 \% \\
\text { critical } \\
\text { value }\end{array}$ & Prob & $\begin{array}{l}\text { ADF } \\
\text { statistics }\end{array}$ & $\begin{array}{l}5 \% \\
\text { critical } \\
\text { value }\end{array}$ & Prob & \\
\hline EXR & $\mathrm{ADF}$ & 0.6758 & -2.8847 & 0.9912 & $-7.7765^{* *}$ & -2.8847 & 0.0000 & I (1) \\
\hline FID & ADF & -1.2950 & -2.8836 & 0.6307 & $-10.2150 * *$ & -2.8839 & 0.0000 & I (1) \\
\hline IFR & $\mathrm{ADF}$ & -1.8849 & -2.8836 & 0.3386 & $-12.3401^{* *}$ & -2.8838 & 0.0000 & I (1) \\
\hline ITR & $\mathrm{ADF}$ & -2.7226 & -2.8841 & 0.0730 & $-9.4569^{* *}$ & -2.8841 & 0.0000 & I (1) \\
\hline LOG(PBS) & ADF & $-4.9357^{* *}$ & -2.8845 & 0.0001 & - & - & - & I $(0)$ \\
\hline LOG(VOT) & $\mathrm{ADF}$ & $-7.9750^{* *}$ & -2.8870 & 0.0000 & - & - & - & I $(0)$ \\
\hline
\end{tabular}

Source: Authors' Computation (2018)

\section{Akaike Information Criterion lag length structure of the ARDL for the Study Model}

In order to examine the study objective, an ARDL approach was employed to conduct an empirical analysis using the Foreign Portfolio Investments in Bond Stocks equation earlier stated in the methodology. The choice of using ARDL approach is because some of the variables are stationary at level and some are at first difference making it suitable for application of ARDL. Before the ARDL bound test for co-integration is conducted, it became imperative to test for the optimal lag length criteria for each variable. The Akaike information criterion was used and the result is presented in Figure 1.

The best fitted ARDL model is selected based on the least Akaike information value. Figure 1 revealed that the optimal lag length is the order of $\operatorname{ARDL}(1,0,2,0,0,0,0)$. The results of the ARDL are presented in Tables 2 and 3. 
Fig 1: Akaike Information Criterion lag length structure of the ARDL for the Study Model Akaike Information Criteria (top 20 models)

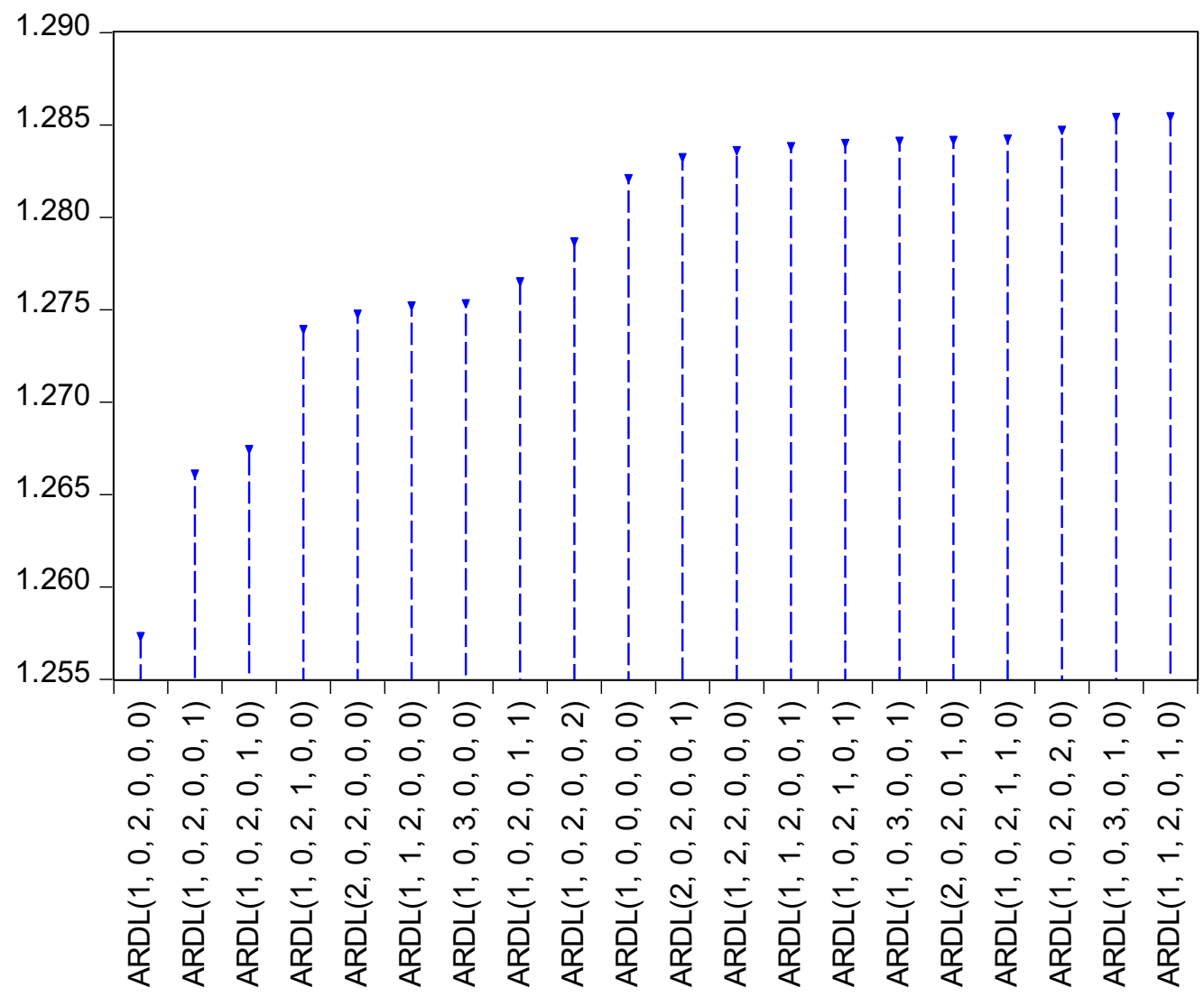

Source: Author's Construct using Data extracted from CBN Statistical Bulletin

\section{Autoregressive Distributed Lag (ARDL) Approach (Bounds) Test for Cointegration}

The ARDL was used to test the hypothesis of the study: Foreign Portfolio Investment in Bond stocks has no significant influence on the Volume of Transactions in the Nigerian Stock Market.

In Table 1, some of the variables were stationary at level others at first difference showing there is a practical difficulty that has to be addressed when we conduct F-test. Exact critical values for the F-test are not available for an arbitrarily mix of I(0) and I(1) variables. However, Peseran, Shin and Smith (2001) prescribed a technique to investigate the appropriate order in which the variables are co-integrated. They suggested a bound for the critical value for the asymptotic distribution of the F-statistic. Table 2 shows that the study model estimated with the computed F-statistic, the model falls above the 5\% upper bound and so we concluded that the variables are I(1) as in $11.754>3.38$.

Table 2: ARDL Bounds Wald statistic Result

\begin{tabular}{|l|l|l|}
\hline \multicolumn{3}{|c|}{ Model } \\
\hline LOS & $\mathbf{I}(\mathbf{0})$ & $\mathbf{I}(\mathbf{1})$ \\
\hline $10 \%$ & 2.08 & 3 \\
\hline $5 \%$ & 2.39 & 3.38 \\
\hline $2.5 \%$ & 2.7 & 3.73 \\
\hline $1 \%$ & 3.06 & 4.15 \\
\hline F-Stat & 11.754 \\
\hline D.F & 5 \\
\hline
\end{tabular}

Source: Researchers' Computation (2018) 


\section{The ARDL Long and Short Run Result for the Study Model}

Table 3 shows in the long run that, the coefficient of foreign portfolio investment in bond stocks is positive and significant at 5\% level. The means that a unit change in foreign portfolio investment in bond stocks will cause the volume of stocks traded to increase by $0.07 \%$. This implies that foreign portfolio investment in bond stocks has a positive and significant effect on the volume of stocks traded in the stock market. This is to say that foreign portfolio investment in bond is one of the major drivers of the volume of stock traded in the Nigerian stock exchange for the study period.

The result in the short run also revealed that foreign portfolio investment in bond stocks has a positive and significant effect on volume of stocks traded on the Nigerian stock exchange and this has the same effect with the outcome in the long run at $0.06 \%$. This implies that there is capital mobility in the stock market. Also, the result reveals that in the long run, the coefficient of financial development is positive and significant. This means that financial development exerts positive effect of on the volume of stocks traded on the Nigerian stock exchange. The implication of this is that a percentage increase in financial development on average will cause the volume of stocks traded to increase by $78 \%$. This is to say that financial development is a major determinant of the volumes of stock traded in the Nigerian stock exchange for the study period. This result however did not conform in the short run.

The result also revealed that in the long run, the coefficient of exchange rate is negatively insignificant. The reason for this could be attributed to the fact that there is a reduction in the value of returns whenever exchange rate depreciates which deters investors from trading in the stock market during the study period. This result however was not so in the short run. This is because investors will first examine if their investment will appreciate in the mean time while watching out for an opportunity to divest in the long run, especially when there is persistent depreciation.

Interest rate in Table 3 also has a positive and significant effect on the volume of stocks traded in the Nigerian stock exchange in the long. This conforms to the $a$ priori expectation that higher interest rate will encourage investors to invest more. This however, was contrary in the short run. Inflation rate also shows a positive but insignificant effect on the volume of stocks traded in the long run.

Table 3: ARDL Long and Short Run Result for the Study Model Dependent Variable: LOG(VOT)

\begin{tabular}{|c|c|c|c|c|c|c|c|}
\hline \multicolumn{4}{|c|}{ Long Run Estimates } & \multicolumn{4}{|c|}{ Short Run Estimates } \\
\hline Variable & Coefficient & t-stat & Prob & Variable & Coefficient & t-stat & Prob \\
\hline LOG(PBS) & $0.065587^{* *}$ & 2.961380 & 0.0038 & $\mathrm{C}$ & $19.16731^{* *}$ & 8.035305 & 0.0000 \\
\hline FID & $0.776177^{* *}$ & 5.766562 & 0.0000 & LOG(VOT) $)_{t-1}$ & $-0.839392^{* *}$ & -8.946082 & 0.0000 \\
\hline EXR & -0.001731 & -0.633588 & 0.5277 & LOG(PBS) & $0.055053^{* *}$ & 2.943239 & 0.0040 \\
\hline IFR & 0.212175 & 1.710674 & 0.0900 & FID $_{t-1}$ & $0.738673^{* *}$ & 4.785356 & 0.0000 \\
\hline ITR & $0.556014^{* *}$ & 4.126373 & 0.0001 & EXR & -0.001453 & -0.634350 & 0.5272 \\
\hline \multirow[t]{5}{*}{$\mathrm{C}$} & $22.83477^{* *}$ & 22.24194 & 0.0000 & IFR & -0.008463 & -0.410587 & 0.6822 \\
\hline & & & & ITR & -0.011506 & -0.282502 & 0.7781 \\
\hline & & & & $\Delta$ (FID) & 2.812643 & 0.547041 & 0.5855 \\
\hline & & & & $\Delta \mathrm{FID}_{\mathrm{t}-1}$ & $0.649849^{* *}$ & 3.266791 & 0.0015 \\
\hline & & & & CointEq $(-1)^{*}$ & $-0.839392^{* *}$ & -9.326089 & 0.0000 \\
\hline
\end{tabular}

\footnotetext{
${ }^{*}$ Implies significant at 5\% ${ }^{* *}$ Implies significant at 1\%
}

Source: Field Work (2018) 


\section{Statistical Properties and Post Diagnostic Results of the Foreign Portfolio Investments in Bond Stocks Model}

The statistical properties of the ARDL result reported in Table 4 revealed that the R-squared value of 0.73 indicates $73 \%$ variation in the volume of stocks traded in the Nigerian stock exchange. This is explained in the model by the explanatory variables. The F-statistics of 3.91 is statistically significant and this shows that there is a considerable harmony between volume of stocks traded in the Nigerian stock exchange and the explanatory variables put together. This confirms that all the measures of foreign portfolio investment in bond stocks jointly have a significant influence on the volume of transactions in the stock market. The Durbin-Watson statistic of 1.99 indicates that there is no serial correlation associated with the regression result as this can be approximated as 2. The Akaike Info Criterion (AIC) and the Schwarz Criterion were relatively low and this shows that the model selection best explains the relationship investigated.

The Post Diagnostic test result using Breusch-Pagan-Godfrey (BPG) tests for the presence of heteroskedasticity in a regression result shows the null hypothesis of no heteroskedasticity. The BPG probability value was greater than $5 \%$ implying there is no presence of heteroskedasticity in the regression result. Also, the result of the B-G Serial Correlation LM probability was 0.91 and this is greater than $5 \%$, hence, we could not reject the null hypothesis of no serial correlation implying that the model has no higher order ARMA $(p)$ correlation. With the probability of the Jarque-Bera test, we concluded that the equation is normally distributed as the probability value is greater than $5 \%$. In the model, the error correction term CointEq $\mathrm{t}_{\mathrm{t}-1}$ is well specified and correctly signed. The coefficient of the CointEq $\mathrm{t}_{\mathrm{t}-1}$ is approximately -0.84 . It means that about $84 \%$ departure from long run equilibrium is corrected in the short run. The negative sign in the CointEq $\mathrm{q}_{\mathrm{t}-1}$ confirms the existence of cointegrating relationship. Hence, about $84 \%$ of the variations in the short run converge in the long run equilibrium.

Table 4: Statistical Properties and Post Diagnostic Results of the Foreign Portfolio Investments in Bond Stocks Model

\begin{tabular}{ll|lc}
\hline \multicolumn{2}{c}{ Statistical Properties of Results } & \multicolumn{2}{c}{ Post Diagnostic Tests Result } \\
\hline R-squared & 0.73 & BPG Heteroskedasticity (F-Stat) & 0.8488 \\
Adj R-squared & 0.67 & BPG Heteroskedasticity Prob. F(8,105) & 0.5621 \\
F-statistic & 3.907 & B-G Serial Correlation LM (F-Stat) & 0.0897 \\
Prob(F-statistic) & 0.000 & B-G Serial Correlation LM Prob. F(8,105) & 0.9143 \\
Durbin-Watson Stat & 1.994 & Ramsey RESET (F-Stat) & 0.3325 \\
Akaike Info Criterion & 1.287 & Ramsey RESET Prob & 0.6398 \\
Schwarz Criterion & 1.503 & Jarque-Bera Statistics & 381.75 \\
& & Jarque-Bera Prob & 0.0000 \\
& & Redundant variable Test (F-stat) & 0.4680 \\
& & Redundant variable Test (Prob) & 0.7372 \\
\hline
\end{tabular}

Source: Field Work (2018)

\section{The CUSUM Stability Test of the ARDL for the study Model}

The Ramsey (Regression Specification Error Test) RESET and the CUSUM test as presented in Figure 2 were used to examine the stability of the ARDL study model. The result revealed that the probability is greater than $5 \%$, hence, we could not reject the null hypothesis. This implies that the model is free from specification error. The CUSUM graph shows the model lies in between the red lines meaning the model is stable in the long run. 
Fig 2: CUSUM Stability Test of the ARDL for the Study Model

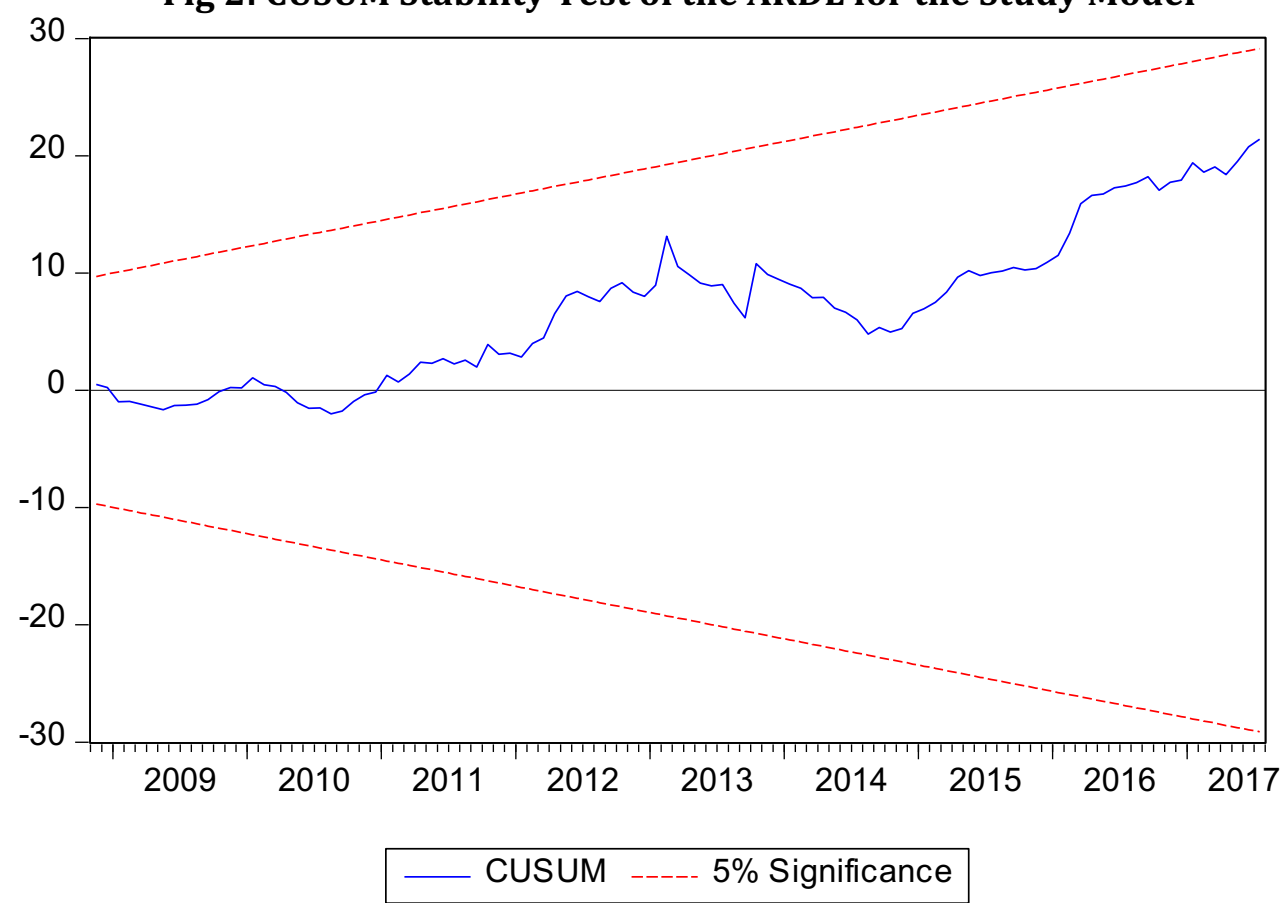

Source: Author's Construct using Data extracted from CBN Statistical Bulletin

\section{Discussion of the Findings from the Study}

Based on the study hypothesis, the result on the relationship between the volume of transactions and foreign portfolio investment in bond stocks is positive and statistically significant. This means that foreign portfolio investment in bond stocks significantly influences the activities of the Nigerian stock market. A unit increase in the flow of foreign portfolio investment in bond stock will induce some level of increase in the volume of transaction in the Nigerian stock market.

Egly et al, (2010) who studied the impact of risk aversion in foreign corporate portfolio investment on the US stock market found that a positive and significant relationship exists between corporate bonds inflow and the stock market returns of the US. The finding of this study is in line with Egly et al. Also, Horioka et al, (2014) found in their study on foreign holdings of Asia's debt securities that a positive and significant relationship exist between the investment in bond stocks from the US and euro zone economies and the stock market of Japan and other Asian bond stock markets.

By implication, increase in foreign portfolio investment in bond stocks led to increase stock market performance in Nigeria during the study period. This finding is consistent with the $a$ priori as well as the conclusion from the study of Mishra and Conteh (2014) that the relationship between this two variables is positive and significant and that a more developed stock market from any economy attracts more foreign portfolio investment. This submission is also in agreement with the outcome of the study by Felman, Gray, Goswami, Jobst, Pradhan, Peiris and Seneviratne (2014), that there is a direct relationship between foreign portfolio investments in bonds and the returns/activities of the stock market.

Similarly, macroeconomic variables such as financial development rate, exchange rates, inflation rates and interest rates for the period under study was used to buttress the related increase in foreign portfolio investment in bond stocks to the Nigerian capital market. The result showed that all the macroeconomic variables together with foreign portfolio investment in bond stock, have a significant influence on the volume of transaction in the stock market, 
which indicates that a consistent flow of this type of investment will encourage improvement and increased performance of the activities in the Nigerian stock market.

\section{CONCLUSION AND RECOMMENDATION}

The study has revealed that foreign portfolio investment in bonds stocks impact a positive and significant effect on the performance of the Nigerian stock market. Thus, considering the dynamic nature of the variables in the long run and short run, the study concludes that foreign portfolio investment inflows through debt/bond stock instruments positively influence the performance of the stock market and consequently deepen the market in Nigeria.

We therefore recommend that the market regulators need to further encourage foreign investments in bond stocks as this financial instruments do not attract much investment as equity stocks. Hence, the introduction of new debt instrument in the Nigerian bond market is a step towards ensuring more investment in this type of instrument. Also, there is need for sound corporate governance and transparency as well as full disclosure of financial information by listed firms in order to increase the attraction of foreign portfolio investment in debt stocks.

\section{References}

Charles, Y. H, Takaaki, N., and Akiko, T.H. (2014). Explaining Foreign Holdings of Asia's Debt Securities. $A D B$ journal, 124(1),1-30.

Dauda, R. (2007) “The impact of FDI on Nigeria's Economic Growth: Trade Policy Matters". Journal of Business and Policy Research, 3(2), 11-26.

Ekeocha, P. (2008). Modelling the Long Run Determinants of Foreign Portfolio Investment in an Emerging Market: Evidence from Nigeria. International Conference on applied Economics, 289-296.

Egly, P., Johnk, D., and Liston, A. D. (2010). Foreign Portfolio Investment Inflows to the United States: The Impact of Investor Risk Aversion and US Stock Market Performance. North American Journal of Finance and Banking Research, 4(4), 25-41.

Elekwa, P., Aniebo, C. and Ogu, C. (2016) Does foreign portfolio investment affect employment growth in Nigeria? Journal of Economics and Sustainable Development, 7(12), 2222-1700.

Felman, J., Gray, S., Goswami, M., Jobst, A.A., Pradhan, M., Peiris, S, and Seneviratne, D. (2014). ASEAN-5 Bond Market Development: Where does it stand? Where is it going? Asian-Pacific Economic Literature, 11(3), 60-75.

Gerlach, R. and Yook, Y. (2016). Political conflict and foreign portfolio investment: Evidence from North Korean attacks. Pacific-Basin Finance Journal, 39(C), 178-196.Mishra and Conteh (2014).

Ghose, A. K. (2004) “Capital inflows and investment in developing countries”. Employment Strategy Papers, 2004 (11).

Idowu, A., \& Babatunde, M. A. (2012). Effect of Financial Reforms on Capital Market Development in Nigeria. Asian Journal of Business and Management Sciences, 8, 44-52.

Lahiri, H. (2012). Foreign portfolio Investment in India and Plausible Exchange Rate and Interest Rate Regimes: policy Options open to the RBI. Contemporary Issues and Ideas in Social Sciences, 5(1), 1-35.

Okpoto, S. (2015). Foreign Private Investment and the Nigeria's Economic Growth. Journal of Policy and Development Studies, 9(3), 30-38.

Osinubi, T. S., and Amaghionyeodiwe, L. A. (2010). Foreign Private Investment And Economic Growth In Nigeria. Applied Econometrics and International Development, 10(2), 189-204.

Roberto, A., and Paul, A. E. (2007). Do International Portfolio Investors Follow Firms' Foreign Investment decisions? Germany: European Central Bank. working Paper Series (815), 1-47.

United Nations Conference on Trade and Development (UNCTAD), "Foreign Direct Investment in Africa", 2005; (Geneva: United Nations, Sales No. E.95.II.A.6). 